\title{
Warning Against the Use of Anti-Inflammatory Medicines to Cure COVID-19: Building Castles in the Air
}

Giustino Varrassi

Received: March 23, 2020 / Published online: April 1, 2020

(C) The Author(s) 2020

Keywords: Anti-inflammatory medicines; COVID-19; NSAIDs

\section{Key Summary Points}

COVID-19 is developing rapidly and invading the whole world in a real pandemic.

There is much discussion, appropriate or less appropriate, of this hot topic.

Recent declarations have focused attention on the risk of interactions between NSAIDs and COVID-19.

There are also theories on the potential interactions between the use of ACE inhibitors, the use of ibuprofen and the increased risk of infection.

At the moment, there are no data in the literature showing that this would be the case.

Enhanced Digital Features To view enhanced digital features for this article go to https://doi.org/10.6084/ m9.figshare.12029571.

\section{G. Varrassi $(\bowtie)$}

Paolo Procacci Foundation, via Tacito 7, 00193 Rome, Italy

e-mail: giuvarr@gmail.com
Pain patients may be reassured by their physicians on the safety of using ACE inhibitors and NSAIDs (especially ibuprofen), because there is nothing to show the potential for an increased risk of viral infection, and especially of COVID-19.

A recent article in Le Figaro has focused attention on the use of anti-inflammatory medicines because they could be responsible for an increased incidence of infections due to COVID-19 [1]. This article reports and emphasizes the opinion of politicians expressed via social media suggesting the use of one medicine instead of others, but not referencing opinions based on scientific data.

A recent article focused its attention on the supposed relationship between chronic pathologies (hypertension and diabetes mellitus) and COVID-19 infection and their pharmacological treatment [2]. The initial assumption is based on two recent papers reporting the clinical experience in China, during the dramatic epidemic now becoming a pandemic $[3,4]$. Both articles suggest that patients affected by COVID-19 frequently had concomitant chronic pathologies, especially hypertension and diabetes mellitus, pathologies that might be treated with angiotensin-converting-enzyme (ACE) inhibitors. Fang et al. [2] 
based their intriguing theory, of an increased risk of COVID-19 infection on patients treated with ACE inhibitors, on the relationship between the ACE system, which can be influenced by anti-inflammatory medicines, and the lung epithelial cells. Following this theory, their conclusion was the most obvious: "...patients ...treated with ACE2-increasing drugs are at higher risk for severe COVID-19 infection...". None of the quoted articles reporting the clinical experience in China has assessed the previous pharmacological therapy of the patients infected by COVID-19 [3, 4].

In the last part of this recent article, the authors suggest that, based on a search on PubMed made on February 28, 2020, there are no reports on the potential influence of calcium channel blockers on ACE2 activity [2]. Therefore, these drugs could be used as an "alternative treatment in these patients". Actually, nobody knows what the pharmacological therapy of the Chinese patients was. Maybe some of them were already using calcium antagonists. Hence, it seems that Fang et al.'s [2] theory is not related to what is reported in the two Chinese papers.

Recently (March 9, 2020), I carried out a very thorough literature search for all the published material on COVID-19. None of the articles found on PubMed reports data connecting the use of ACE-inhibitors or NSAIDs to an increased incidence or risk of COVID-19 infection. I am not excluding that it might be shown in the future, when the literature will have more clear and valid scientific information, but at the moment it seems very premature. I think that, especially in a dramatic moment like the one we are living in, it would be more prudent to prevent the temptation to build castles in the air.

\section{ACKNOWLEDGEMENTS}

Funding. This article has been possible thanks to the unconditional support of the Paolo Procacci Foundation. No Rapid Service Fee was received by the journal for the publication of this article.
Authorship. The named author meets the International Committee of Medical Journal Editors (ICMJE) criteria for authorship for this article, takes responsibility for the integrity of the work as a whole, and has given approval for this version to be published.

Disclosures. Giustino Varrassi is a section editor of this journal.

Compliance with Ethics Guidelines. The article is based on previously conducted studies and publications, and does not contain any studies with human participants or animals performed by the author.

Data Availability. Data sharing is not applicable to this article as no datasets were generated or analyzed during the current study.

Open Access. This article is licensed under a Creative Commons Attribution-NonCommercial 4.0 International License, which permits any non-commercial use, sharing, adaptation, distribution and reproduction in any medium or format, as long as you give appropriate credit to the original author(s) and the source, provide a link to the Creative Commons licence, and indicate if changes were made. The images or other third party material in this article are included in the article's Creative Commons licence, unless indicated otherwise in a credit line to the material. If material is not included in the article's Creative Commons licence and your intended use is not permitted by statutory regulation or exceeds the permitted use, you will need to obtain permission directly from the copyright holder. To view a copy of this licence, visit http://creativecommons.org/licenses/by$\mathrm{nc} / 4.0 /$.

\section{REFERENCES}

1 https://www.lefigaro.fr/sciences/coronavirus-alerte-sur1-ibuprofene-et-autres-anti-inflammatoires-20200314. Accessed 15 Mar 2020.

2 Fang L, Karakiulakis G, Roth M. Are patients with hypertension and diabetes mellitus at increased risk 
for COVID-19 infection? Lancet Respir Med. 2020. https://doi.org/10.1016/PII (published on line March 11).

3 Yang X, Yu Y, Xu J, et al. Clinical course and outcomes of critically ill patients with SARS-CoV-2 pneumonia in Wuhan, China: a single-centered, retrospective, observational study. Lancet Respir Med. 2020. https://
doi.org/10.1016/S2213-2600(20)30079-5 (published online Feb 24).

4 Guan W, Ni Z, Hu Y, et al. Clinical characteristics of coronavirus disease 2019 in China. N Engl J Med. 2020. https://doi.org/10.1056/NEJMoa2002032 (published online Feb 28). 